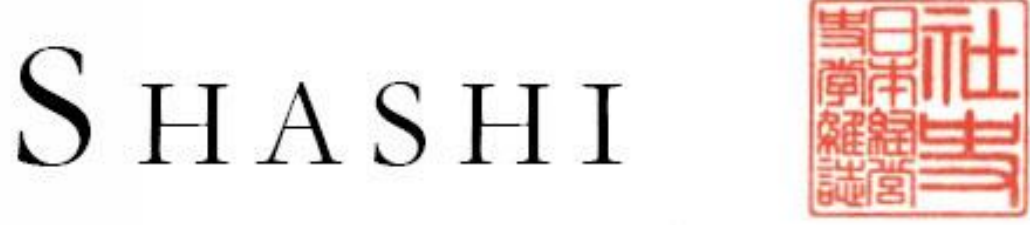

The Journal of Japanese Business and Company History

Vol.5, No. 1 (2020) a ISSN 2169-0820(Online) a DOI 10.5195/shashi.2020.41 a http://shashi.pitt.edu

\section{Shashi Related to the Japanese Company Histories Interest Group Panel at AAS 2016}

\author{
Yuriko Kadokura \\ Shibusawa Eiichi Memorial Foundation
}

【No.】1E

【Company Name (Romanized Japanese)】 Honda Giken Kōgyō Kabushiki Kaisha

【English Name (at time of shashi publication )】 Honda Motor Co., Ltd.

【Shashi Title (Romanized Japanese)】Kataritsugitai koto: Charenji no 50-nen, Sōshūhen "Ōinaru yume no jitsugen"

【English Translation of Title】 What I Want to Pass Down: 50 Years of Challenges, Summary "Realizing a Great Dream"

【Year of Publication】 1999

【Company and Shashi Overview】 : After WW II, Honda Sōichirō (1906-1991), who had been manufacturing automobile pistons in Shizuoka, developed an auxiliary engine for bicycles. In 1946 he founded the Honda Gijutsu Kenkyūjo (Honda Institute of Technology), which became a joint-stock company in 1948. The following year Fujisawa Takeo (1910-1988) joined the company as managing director and business was expanded to the Tokyo area. The company focused on product development and manufacture with the goal of becoming the foremost motorcycle manufacturer in the world. Early achievements included the release of the "Super Cub" in 1958 and participation in the Isle of Man TT Race the following year. The 50-year history consists of a summary volume entitled Öinaru yume no jitsugen (Realizing a Great Dream), a supplementary volume with chronological tables and documents, and two CD-ROMs entitled " 12 no bumon de tsuzuru 50-nen" (50 Years in 12 Departments) and "Eizō to oto de tsuzuru 50-nen" (50 Years in Video and Sound). The summary volume includes specific vignettes of the dreams and the passion for manufacturing that demonstrate how the founder's spirit has penetrated every aspect of corporate culture.

【SSD (Shibusawa Shashi Database) Link】

Summary volume: http://shashi.shibusawa.or.jp/details_basic.php?sid=6780

Chronological tables and documents: http://shashi.shibusawa.or.jp/details_basic.php?sid=6790

【Shashi Wiki】https://library.osu.edu/wikis/shashidb/index.php/Honda_Motor_Co

【No.】2E

【Company Name (Romanized Japanese)】 Toyota Jidōsha Kōgyō Kabushiki Kaisha

【English Name (at time of shashi publication )】 Toyota Motor Co., Ltd.

【Shashi Title (Romanized Japanese)】Toyota no ayumi: Toyota Jidōsha Kōgyō Kabushiki Kaisha sōritsu 40-shūnen kinen

【English Translation of Title】 Toyota History: Commemorating the 40th Anniversary of Toyota Motor Co., Ltd.

【Year of Publication】: 1978 
【Company and Shashi Overview】Toyoda Sakichi (1867-1930) from Shizuoka attended the Third Domestic Industrial Exhibition in 1890 in Tokyo, where he learned about power machinery. This knowledge enabled him to invent the first Japanese power loom. He established Toyoda Automatic Loom Works Ltd. in Aichi Prefecture in 1926, but his son Toyoda Kiichirō (1894-1952) turned to research on automobiles. Kiichirō studied the newest industrial technologies with the goal of manufacturing a domestic car for the masses. In 1937 he gained his independence with the establishment of Toyota Motor Co., Ltd. The new company had a factory layout based on assembly-line production without stockpiles and was committed to efficiency and quality control. In 1950 the sales division separated to form Toyota Motor Sales Co., Ltd. The set of shashi published to mark the 40th anniversary of the company's establishment (including Watashi to kuruma and Wa, waza, wadachi) explores the theme of "the role of cars in civilization."

【SSD Link】 http://shashi.shibusawa.or.jp/details_basic.php?sid=6650

【Shashi Wiki】https://library.osu.edu/wikis/shashidb/index.php/Toyota_Jidosha_Kogyo

\section{【No.】 3E}

【Company Name (Romanized Japanese)】Toyota Jidōsha Kōgyō Kabushiki Kaisha

【English Name (at time of shashi publication )】 Toyota Motor Co., Ltd.

【Shashi Title (Romanized Japanese)】 Watashi to kuruma: Toyota Jidōsha Kōgyō Kabushiki Kaisha sōritsu 40shūnen kinen ronbunsh $\bar{u}$

【English Translation of Title】 Me and Cars: A Collection of Essays Commemorating the 40th Anniversary of Toyota Motor Co., Ltd.

【Year of Publication】 1977

【Company and Shashi Overview】 Established in 1937, Toyota Motor Co., Ltd. marked its 40th anniversary by publishing a three-volume set of company histories on the theme of "the role of cars in civilization." This volume comprises the top 18 essays from 1,994 submissions gathered in a "national appeal for essays and opinion pieces" conducted as part of the commemoration project.

【SSD Link】http://shashi.shibusawa.or.jp/details_basic.php?sid=6640

【Shashi Wiki】https://library.osu.edu/wikis/shashidb/index.php/Toyota_Jidosha_Kogyo

【No.】 $4 \mathrm{E}$

【Company Name (Romanized Japanese)】Toyota Jidōsha Kōgyō Kabushiki Kaisha

【English Name (at time of shashi publication )】 Toyota Motor Co., Ltd.

【Shashi Title (Romanized Japanese)】Wa, waza, wadachi: Toyota Jidōsha Kōgyō Kabushiki Kaisha sōritsu 40shūnen kinen shashinshū

【English Translation of Title】 Wheels, Skills and Tracks: A Collection of Photographs Commemorating the 40th Anniversary of Toyota Motor Co., Ltd.

【Year of Publication】 1978

【Company and Shashi Overview】 Established in 1937, Toyota Motor Co., Ltd. marked their 40th anniversary by publishing a three-volume set of company histories on the theme of "the role of cars in civilization." This volume is a collection of photographs on eight themes including development, manufacturing, products, employees, and advertisements.

【SSD Link】http://shashi.shibusawa.or.jp/details_basic.php?sid=6660

【Shashi Wiki】 https://library.osu.edu/wikis/shashidb/index.php/Toyota_Jidosha_Kogyo

【No.】5E

【Company Name (Romanized Japanese)】Toyota Jidōsha Hanbai Kabushiki Kaisha

【English Name (at time of shashi publication )】 Toyota Motor Sales Co., Ltd. 
【Shashi Title (Romanized Japanese)】Mōtarizēshon to tomo ni

【English Translation of Title】: Together with Motorization

【Year of Publication】 1970

【Company and Shashi Overview】 As part of post-WWII restructuring, Toyota separated the sales division from the rest of the company and established Toyota Motor Sales Co., Ltd. in 1950. After this, Toyota Motor Sales developed latent demand and worked towards expanding their market from domestic to global. This shashi covers the developments of Toyota Motor Sales' first twenty years against a backdrop of corporate expansion. There is also a separate volume of materials. [The companies underwent a merger in 1982 that resulted in the birth of Toyota Motor Corporation.]

【SSD Links】Main volume: http://shashi.shibusawa.or.jp/details_basic.php?sid=6670

Materials: http://shashi.shibusawa.or.jp/details_basic.php?sid=6680

【Shashi Wiki】https://library.osu.edu/wikis/shashidb/index.php/Toyota_Jidosha_Hanbai

\section{【No.】 6E}

【Company Name (Romanized Japanese)】 Toyota Jidōsha Kabushiki Kaisha

【English Name (at time of shashi publication )】 Toyota Motor Corporation

【Shashi Title (Romanized Japanese)】 Sōzō kagirinaku: Toyota Jidōsha 50-nenshi

【English Translation of Title】 Limitless Creation: Toyota Motor Corporation 50-Year History

【Year of Publication】 1987

【Company and Shashi Overview】 This 50-year history of the Toyota Motor Corporation starts with a prologue containing a short biography of Toyoda Sakichi and then describes the 50 years since the founding of Toyota Motor Co., Ltd. in 12 chronologically ordered chapters. In 1950 the sales division separated to establish itself as Toyota Motor Sales Co., Ltd., but the companies were merged in 1982 leading to the birth of Toyota Motor Corporation. The book also details the company's modernization starting with the "kanban system" (just-in-time inventory management system). There is an index at the end and a separate volume of collected materials.

【SSD Links】 Main volume: http://shashi.shibusawa.or.jp/details_basic.php?sid=6610

Materials: http://shashi.shibusawa.or.jp/details_basic.php?sid=6620

【Shashi Wiki】 https://library.osu.edu/wikis/shashidb/index.php/Toyota_Jidosha

【No.】 7E

【Company Name (Romanized Japanese)】 Toyota Jidōsha Kabushiki Kaisha

【English Name (at time of shashi publication )】 Toyota Motor Corporation

【Shashi Title (Romanized Japanese)】 Ōinaru yume, jōnetsu no hibi: Toyota sōgyōki shashinshū

【English Translation of Title】 Great Dreams, Days of Passion: A Photographic History of Toyota's Early Days

【Year of Publication】 1999

【Company and Shashi Overview】This shashi is a collection of photographs illustrating the work of Toyota Motor Corporation, especially founder Toyoda Kiichirō. The photographs of products, people, and factories have been divided into six chronological sections covering a period from Kiichirō's birth in 1894 until 1955, three years after his death.

【SSD Link】http://shashi.shibusawa.or.jp/details_basic.php?sid=6630

【Shashi Wiki】 https://library.osu.edu/wikis/shashidb/index.php/Toyota_Jidosha

【No.】 $8 \mathrm{E}$

【Company Name (Romanized Japanese)】 : Toyota Jidōsha Kabushiki Kaisha

【English Name (at time of shashi publication )】 Toyota Motor Corporation

【Shashi Title (Romanized Japanese)】 Toyota Jidōsha 75-nenshi

【English Title】 75 Years of Toyota

【Year of Publication】 : 2013 
【Company and Shashi Overview】 Toyota Motor Corporation's 75-year history consists of three parts. The first part, "Taking on the Automotive Business," includes transcriptions of Toyoda Sakichi's inventions and covers the period from Toyoda Kiichirō's first foray into the automobile business in 1937 to preparations for post-WWII mass production and sales in the mid-1950s. Part 2, "Entering the Automotive Business," covers the establishment of systems for mass production, the development of new car models, and the response to social demands in the late 1970s. Part 3, "Leaping Forward as a Global Corporation," covers overseas production, globalization, and management crises from the merger of the production and sales arms of the company to the 2010s. There is an index at the end and a separate volume of collected materials. 75 Years of Toyota was first published in 2012 in digital form on the official website of the Toyota Motor Corporation before being published in print form the following year.

\section{【SSD Links】}

Main volume: http://shashi.shibusawa.or.jp/details_basic.php?sid=6633

Materials: http://shashi.shibusawa.or.jp/details_basic.php?sid=6635

【Shashi Wiki】 https://library.osu.edu/wikis/shashidb/index.php/Toyota_Jidosha

【No.】9E

【Company Name (Romanized Japanese)】 Nissan Jidōsha Kabushiki Kaisha

【English Name (at time of shashi publication )】 Nissan Motor Co., Ltd.

【Shashi Title (Romanized Japanese)】21-seiki e no michi: Nissan Jidōsha 50-nenshi

【English Translation of Title】 : Road to the 21st Century: 50-Year History of Nissan Motor Co., Ltd.

【Year of Publication】 1983

【Company and Shashi Overview】The Kaishinsha Jidōsha Kōjō (Kaishinsha Motor Car Works) was founded in 1911 and succeeded in the production of a small passenger car known as the DAT automobile in 1914. The company was later renamed Datto Jidōsha Seizō (DAT Automobile Manufacturing). Tobata Imono (Tobata Casting) was founded by Aikawa Yoshisuke (1880-1967) at roughly the same time and started manufacturing automobile parts around 1928. Aikawa recognized the future possibilities of the automobile industry and bought DAT Automobile Manufacturing in 1931 with the goal of producing cars domestically. Aikawa's company merged with Ishikawajima Jidōsha Seisakujo (Ishikawajima Automobile Factory), leading to the establishment of Jidōsha Seizō Kabushiki Kaisha (Automobile Manufacturing Co., Ltd.) in 1933 with Aikawa as the first president. Automobile Manufacturing Co., Ltd. was brought under the umbrella of Nihon Sangyō (Japan Industry), a holding company established by Aikawa, and renamed Nissan Motor Co., Ltd. in 1934. The shashi covers the company's first fifty years and is written in an easy-to-read format with numerous photographs.

【SSD Link】 http://shashi.shibusawa.or.jp/details_basic.php?sid=6730

【Shashi Wiki】 https://library.osu.edu/wikis/shashidb/index.php/Nissan_Motor_Co.,_Ltd.

【No.】 $10 \mathrm{E}$

【Company Name (Romanized Japanese)】 Nissan Jidōsha Kabushiki Kaisha

【English Name (at time of shashi publication )】 Nissan Motor Co., Ltd.

【Shashi Title (Romanized Japanese)】 Nissan Jidōsha shashi: 1974-1983

【English Translation of Title】The History of Nissan Motor Co., Ltd.: 1974-1983

【Year of Publication】1985

【Company and Shashi Overview】 This shashi follows chronologically from the three shashi previously published by Nissan (30-nenshi: 1933-1963 [30-year History: 1933-1963], Shashi: 1964-1973 [Company History: 19641973], and 50-nenshi: 1933-1983 [50-year History: 1933-1983]), and covers the years 1974-1983. It describes how the company responded to the first and second oil crises from the viewpoint of each department.

【SSD Link】 http://shashi.shibusawa.or.jp/details_basic.php?sid=6740

【Shashi Wiki】https://library.osu.edu/wikis/shashidb/index.php/Nissan_Motor_Co.,_Ltd. 
【No.】 $11 \mathrm{E}$

【Company Name (Romanized Japanese)】 Kikkōman Kabushiki Kaisha

【English Name (at time of shashi publication )】 Kikkoman Shoyu Co., Ltd.

【Shashi Title (Romanized Japanese)】 Kikkōman Shōyu shi

【English Translation of Title】 The History of Kikkoman Shoyu Co., Ltd.

【Year of Publication】 1968

【Company and Shashi Overview】Soy sauce production in Noda began in the Muromachi period and due to plentiful raw materials and convenient water transport, the industry flourished in the Edo period. In the Meiji period producers expanded sales channels to a national scale and incorporated mechanization. Noda Shōyu Kabushiki Kaisha (Noda Soy Sauce Co., Ltd.) was established in 1917 as a joint family venture. In 1964 the company was renamed Kikkoman Shoyu Co., Ltd. after its long-time trademark. The shashi compiled to mark the fiftieth anniversary adds many documents and illustrations to the contents of the previously published twenty- and thirtyyear histories and also includes an appendix with further discussion of "soy sauce and the history of food" in Japan.

【SSD Link】http://shashi.shibusawa.or.jp/details_basic.php?sid=1030

【Shashi Wiki】 https://library.osu.edu/wikis/shashidb/index.php/Kikkoman

\section{【No.】 12E}

【Company Name (Romanized Japanese)】 Kikkōman Kabushiki Kaisha

【English Name (at time of shashi publication )】 Kikkoman Corporation

【Shashi Title (Romanized Japanese)】 Kikkōman Kabushiki Kaisha hachiju nenshi

【English Translation of Title】 Eighty Year History of Kikkoman Corporation

【Year of Publication】 2000

【Company and Shashi Overview】 In 1917, eight family soy sauce brewers including the Mogi and Takanashi families of Noda, Chiba prefecture, and the Horikiri family of Nagareyama joined together and founded Noda Shōyu Kabushiki Kaisha (Noda Soy Sauce Co., Ltd.). The first president was Mogi Shichirōemon (1860-1929). This shashi starts with an overview of the use of seasoning in food from pre-historic times and a brief introduction to the history of soy sauce. It goes on to describe how the company successfully freed itself from the post-war period single-minded focus on soy sauce and shifted to a management philosophy that embraced diversification and internationalization. The company changed its name in 1964 to Kikkoman Shoyu Co., Ltd. and then in 1980 to Kikkoman Corporation. Although the shashi has only a simple chronology, it has a detailed table of contents.

【SSD Link】http://shashi.shibusawa.or.jp/details_basic.php?sid=1040

【Shashi Wiki】 https://library.osu.edu/wikis/shashidb/index.php/Kikkoman

【No.】 $13 \mathrm{E}$

【Company Name (Romanized Japanese)】 Ajinomoto Kabushiki Kaisha

【English Name (at time of shashi publication )】 Ajinomoto Co., Inc.

【Shashi Title (Romanized Japanese)】 Ajinomoto enkakushi

【English Translation of Title】 The History of Ajinomoto

【Year of Publication】 1951

【Company and Shashi Overview】Suzuki Seiyakusho Co. was established in 1907 by Suzuki Saburōsuke II (18671931), who was involved in the manufacture of iodine and other products. He collaborated with Dr. Ikeda Kikunae (1864-1936), who had obtained a patent for umami (the fifth taste) extracted from kelp, to try and industrialize the production process. They called the MSG they produced "aji-no-moto" and began selling it in 1909. The company expanded, establishing distributors throughout the country, and reorganized as a limited partnership company ( gōshi kaisha) under the name Suzuki Shōten (Suzuki Store) in 1912. Further expansion of the sales structure and product development led to the company's reorganization as an incorporated public company (kabushiki kaisha) in 1917. Expansion continued with the development of international markets, but later stalled when production was stopped during WWII. After the war ended production restarted and, in 1946, the company strengthened its capital stock and was renamed Ajinomoto Co., Inc. This shashi was compiled to mark the forty years since the 
start of work on the industrial manufacture of umami and contains the history of and records related to seasonings and culture (chapters 1-2), overseas development and the history of various departments (chapters 3-7), and memoirs. Various materials including advertisements and diagrams illustrating the manufacturing process are included in the main body of the shashi. [Suzuki Saburōsuke also served as the managing director of Nippon Kagaku Kōgyō Kabushiki Kaisha (Japan Chemical Industry Co., Ltd.), which had been initiated by Shibusawa Eiichi and others.]

【SSD Link】http://shashi.shibusawa.or.jp/details_basic.php?sid=960

【Shashi Wiki】 https://library.osu.edu/wikis/shashidb/index.php/Ajinomoto

【No.】 $14 \mathrm{E}$

【Company Name (Romanized Japanese)】 Ajinomoto Kabushiki Kaisha

【English Name (at time of shashi publication )】 Ajinomoto Co., Inc.

【Shashi Title (Romanized Japanese)】 Ajinomoto Kabushiki Kaisha shashi

【English Translation of Title】The History of Ajinomoto Co., Inc.

【Year of Publication】 1971

【Company and Shashi Overview】 This shashi was compiled to mark the sixtieth anniversary of the launch of "ajino-moto" and consists of two volumes, one each on the pre- and post-WWII periods. The first volume starts with the Suzuki family's production of iodine and covers the period until the financial difficulties of WWII. The second volume starts with the company's revival after the war and covers the period until the diversification and internationalization of the 1960s. Although the previously published Ajinomoto enkakushi (The History of Ajinomoto) was an in-house project, this shashi was compiled by the Japan Business History Institute under the supervision of economist Tsuchiya Takao. Both volumes include prefatory remarks by authoritative organic chemists Dr. Sakaguchi Kin'ichirō and Dr. Akahori Shirō and volume one includes folklorist Miyamoto Tsuneichi's "Nihon ni okeru chōmiryō no rekishi" (The History of Seasonings in Japan).

【SSD Links】

Volume 1: http://shashi.shibusawa.or.jp/details_basic.php?sid=970

Volume 2: http://shashi.shibusawa.or.jp/details_basic.php?sid=980

【Shashi Wiki】 https://library.osu.edu/wikis/shashidb/index.php/Ajinomoto

\section{【No.】 $15 \mathrm{E}$}

【Company Name (Romanized Japanese)】Ajinomoto Kabushiki Kaisha

【English Name (at time of shashi publication )】 Ajinomoto Co., Inc.

【Shashi Title (Romanized Japanese)】 Aji wo tagayasu: Ajinomoto hachiju nenshi

【English Translation of Title】Cultivating Taste: Eighty Year History of Ajinomoto

【Year of Publication】 1990

【Company and Shashi Overview】 This two-section shashi is an 80-year history of the company from its establishment in 1908. Section 1 covers the pre-WWII period and comprises a prologue entitled "Ikeda Kikunae to nidai Saburōsuke" (Ikeda Kikunae and Saburōsuke II) followed by three chapters. It is written in a clear, narrative style. Section 2 covers the later period, from the post-war era until 1988, and comprises four chapters divided chronologically that each take a business history approach including discussion from production, market, and organizational standpoints. There is also an index at the end.

【SSD Link】http://shashi.shibusawa.or.jp/details_basic.php?sid=990

【Shashi Wiki】 https://library.osu.edu/wikis/shashidb/index.php/Ajinomoto

【No.】 $16 \mathrm{E}$

【Company Name (Romanized Japanese)】 Nihon Kōkū Kabushiki Kaisha 
【English Name (at time of shashi publication )】 Japan Air Lines Co., Ltd.

【Shashi Title (Romanized Japanese)】 Nihon Kōkū 10-nen no ayumi: 1951-1961

【English Translation of Title】 Ten years of Progress: Japan Air Lines, 1951-1961

【Year of Publication】 1964

【Company and Shashi Overview】 Japan's aviation industry had completely collapsed by the end of WWII and flights were operated solely by foreign airlines. A movement to rebuild domestic private airline companies met with success when the Occupation forces granted a business permit leading to the establishment of Japan Air Lines Co., Ltd. (Nihon Kōkū Kabushiki Kaisha) in 1951. The company was reorganized as a semi-governmental corporation with the issuing of the Japan Air Lines Act in 1953. This shashi was planned as part of the celebrations for the tenth anniversary of the founding of the company and starts with "Sōgyō no keii" (The Story of the Founding), followed by "Puropera no jidai" (The Propeller Age) and "Jetto jidai no kaimaku" (The Dawn of the Jet Age). Various materials have been included as well as feature articles with abridged English translations and many illustrations. [The company's official English name was written as Japan Air Lines until 1989 when it was changed to Japan Airlines.]

【SSD Link】http://shashi.shibusawa.or.jp/details_basic.php?sid=12920

【Shashi Wiki】 https://library.osu.edu/wikis/shashidb/index.php/Nihon_Koku

【No.】 $17 \mathrm{E}$

【Company Name (Romanized Japanese)】 Nihon Kōkū Kabushiki Kaisha

【English Name (at time of shashi publication )】 Japan Air Lines Co., Ltd.

【Shashi Title (Romanized Japanese)】 Nihon Kōkū 20-nenshi: 1951-1971

【English Translation of Title】 Twenty Year History of Japan Air Lines: 1951-1971

【Year of Publication】 1974

【Company and Shashi Overview】 This shashi was compiled as part of celebrations to mark the 20th anniversary of the founding of Japan Air Lines Co., Ltd. The three sections are divided chronologically into three periods referred to as "establishment," "growth," and "rapid progress." Each section is further divided into three parts: management, technology, and business environment; with each part written by external scholars in the various subjects. The supplementary section, entitled "Kōkū yusō zenshi" (Early Air Transportation History) looks at the history of aviation before WWII both within Japan and around the world.

【SSD Link】 http://shashi.shibusawa.or.jp/details_basic.php?sid=12930

【Shashi Wiki】 https://library.osu.edu/wikis/shashidb/index.php/Nihon_Koku

\section{【No.】 $18 \mathrm{E}$}

【Company Name (Romanized Japanese)】 : Nihon Kōkū Kabushiki Kaisha

【English Name (at time of shashi publication )】 Japan Air Lines Co., Ltd.

【Shashi Title (Romanized Japanese)】 Nihon Kōkū shashi: 1971-1981

【English Translation of Title】 Japan Air Lines Thirty Year Company History: 1951-1981

【Year of Publication】 1985

【Company and Shashi Overview】 This shashi was compiled as part of celebrations to mark the 30th anniversary of the founding of Japan Air Lines Co., Ltd. Carrying on the editorial policies of the previously published Nihon Kōku 20-nenshi (Twenty Year History of Japan Air Lines), it focuses on the company's third decade . The prologue provides a summary of the first twenty years of the company's history and is followed by three chapters divided chronologically, and a final chapter on the latest developments. There is also an index at the end.

【SSD Link】http://shashi.shibusawa.or.jp/details_basic.php?sid=12940

【Shashi Wiki】https://library.osu.edu/wikis/shashidb/index.php/Nihon_Koku 


\section{(c)) EY}

New articles in this journal are licensed under a Creative Commons Attribution 3.0 United States License.

\section{ULIS D-Sunt}

This journal is published by the University Library System, University of Pittsburgh as part of its D-Scribe Digital Publishing Program and is cosponsored by the University of Pittsburgh Press. 